\title{
sience \& Efficacy of Some Botanical Extracts on Plant Growth, Yield and Pest Management in Eggplant Field
}

\author{
M. A. K. Azad* and S. K. Sarker
}

Institute of Environmental Science, University of Rajshahi, Rajshahi 6205

*Corresponding author: akazad_ies@yahoo.com

\begin{abstract}
An experiment was conducted to evaluate the efficacy of nine botanical extracts on plant growth, yield and pest management in eggplant field. Aqueous extracts of dried leaves of Nicotiana tabacum, Aegle marmelos, Ficus hispida, Lawsonia inermis, Vitex negundo and seeds of Carum roxburghianum, Corchorus capsularis and Swietenia macrophylla and bulb of Allium sativum were prepared and sprayed in experimental eggplant field at University of Rajshahi during January 1, 2014 to May 5, 2014. Out of these nine botanicals, Nicotiana tabacum extract showed best performance against pest attack in eggplant field. The leaf extract of Ficus hispida also showed good efficacy in the protection of eggplant from pest attack. The highest plant length and fruit yield were recorded in the treatment of Nicotiana tabacum, whereas second and third highest productions were observed in Aegle marmelos and Ficus hispida treatments, respectively. Both Allium sativum and Carum roxburghianum extracts were found to show phyto-toxicity to eggplant and hampered the plant growth and yield.
\end{abstract}

Key words: Botanical extracts, Efficacy, Eggplant, Growth and Yield

\section{Introduction}

Eggplant (Solanum melongena L.) belongs to the family of Solanaceae, is one of the most popular and nutritious vegetables worldwide. Adaptability to wide range of soil and climate is the main reason for its worldwide extensive cultivation. China is the first in cultivating and consuming eggplant. It is a cheap source of carbohydrate and vitamins. In a sub-tropical country like Bangladesh, eggplant is grown all over the country on medium high land to high land in both Rabi and Kharif seasons. Its position is $2^{\text {nd }}$ next to potato as per cultivation area, production, yield and consumption. Eggplant is attacked by a number of pests, nematodes and disease causing fungi at various stages. Among them, eggplant shoot and fruit borers, stem borer, leaf sucker, leaf hoppers and epilachna beetles cause serious damage to the crop (BARI, 1995). One of the major factors of low yield of eggplant is pest attack. The eggplant leaf sucker has been found to be a serious pest of brinjal in Bangladesh. Both the nymphs and adults of hopper cause serious damage to leaves by sucking the cell sap. The small nymphs suck sap from the lower surface of the leaves. The entire plant turns brown and show burn symptom and ultimately the leaves droop off.

The use of conventional insecticides has raised some concern about their threat to the environment (Huang et al., 1998). Therefore, there is an imperative need for the development of safer, alternative crop protectants such as botanical insecticides. Current pest control technology is based largely on imported synthetic insecticides, which are frequently priced beyond the small farmers, who constitute a very large proportion of the farming population in Bangladesh.

Moreover, many insects been reported to be resistance to chemical insecticides ( Halliday et al., 1988). This problem has increased the need for effective and biodegradable pesticides with greater selectivity. Bangladesh and many other Asian countries are rich in plant products and traditionally used by the rural inhabitants for medicinal purpose and in some instance as preparations for insect control (Talukdar and Howse,
1993). Botanical insecticides tend to have broad spectrum activity, are relatively specific in their mode of action, and easy to process and use in farm-levels. They are also safe for higher animals and the environment (Anonymous, 1991). Botanical insecticides can often be easily produced by farmers and small-scale industries with indigenous plant materials. These are cheaper and hazard free in comparison to chemical insecticides (Saxena et al., 1980). Plants are rich sources of natural substances that can be utilized in the development of environmentally safe methods for insect control (Sadek, 2003). Crude plant extracts often consist of complex mixtures of active compounds, they many show greater overall bioactivity compared to the individual constituents (Berenbaum et al., 1991; Chen et al.,1995). The deleterious effects of crude plant extracts on insects were manifested in several ways, including toxicity (Hiremath et al., 1997) and feeding inhibition (Klepzig and Schlyter, 1999; Wheeler and Isman, 2001). Certain plant families, particularly Meliaceae, Rutaceae, Asteraceae, Labiateae, Piperaceae and Annonaceae were viewed as exceptionally promising sources of plant-based insecticides (Jacobson, 1989; Schmutter, 1990; Isman, 1995).

Bangladesh is rich in plant biodiversity. Therefore, research on botanical pesticides has a good scope of study to find out the suitable combinations and formulations of different indigenous botanicals to produce an eco-friendly plant based pesticide for sustainable pest management. This study was carried out to find out the efficacy of nine botanicals on plant growth, yield and eco-friendly pest management in eggplant field without hampering the nature.

\section{Materials and Methods}

\section{Field Preparation and Experimental Period}

The experiment was conducted at IES Research Field of University of Rajshahi during January 01, 2014 to May 05,2014 . The land of the experimental plot was ploughed with power tiller and was pulverized by 4 times ploughing followed by laddering. The weeds and stubbles were removed from the field. The soil was 
properly leveled for planting. After opening the land, well decomposed cowdung was applied and thoroughly mixed up with soil. Before final land preparation, inorganic fertilizers were applied as per Fertilizer Recommendation Guideline of BARC. Several holes were made every $50 \mathrm{~cm}$ interval and line to line 1 meter. About 30-35 days old eggplant seedling (local variety Kanta Begun) were purchased from local Katakhali bazar, Rajshahi and planted in each hole. Watering and other intercultural operations were done as and when necessary.

\section{Preparation of Botanical Extracts}

Plant materials of Ficus hispida, Aegle marmelos, Nicotiana tabacum, Lawsonia inermis, Vitex negundo, Allium sativium, Carum roxburghianum, Corchorus capsularis and Swietenia macrophylla were collected from Rajshahi area (Table 1).

Table 1. Plant parts used for botanical extract preparation

\begin{tabular}{|l|l|l|}
\hline Names of plants & Scientific name & Plant parts used \\
\hline Mehidi & Lawsonia inermis & Leaves \\
\hline Nishinda & Vitex negundo & Leaves \\
\hline Tobacco & Nicotiana tabacum & Leaves \\
\hline Garlic & Allium sativum & Bulb \\
\hline Soj & Carum roxburghianum & Seeds \\
\hline Bell & Aegle marmelos & Leaves \\
\hline Khoksha & Ficus hispida & Leaves \\
\hline Jute & Corchorus capsularis & Seeds \\
\hline Mahogani & Swietenia macrophylla & Seeds \\
\hline
\end{tabular}

Before grinding or cutting, plant parts were dried in lab for 20-25 days. About $100 \mathrm{gm}$ of leaf dusts or grinding seeds were dissolved in one litre of tap water in a plastic bucket and kept for three days and filtered through white markin cloth and preserved in refrigerator until use.

\section{Spray of Botanical Extracts and Pest Attack Monitoring}

The botanical extract was sprayed on eggplant experimental plot twice a week with the help of a sprayer. The pest attack and damages were monitored every 3- days in a week. The numbers of infested leaves were also recorded.

\section{Experimental Plot Design}

The experimental plot was arranged as per CRD with three replications. Nine botanical treatments and one control (tap water) were used in this experiment.

All data were analyzed by ANOVA and means are separated using Duncun's Multiple Range Tests $(\mathrm{p}=0.05)$.

\section{Results and Discussion}

In this study, efficacy of nine botanical extracts was tested in experimental eggplant field. Out of nine botanicals, Nicotiana tabacum leaves extract showed excellent performance against the pest attack of eggplant leaves $(3.63 \pm 0.96)$ compare to control (8.80 \pm 0.50$)$. Ficus hispida leaf extract was also found to show good performance against the leaves attack

Table 2. Effect of plant extract against pest attack on eggplant leaves

\begin{tabular}{|l|l|l|l|}
\hline Sl. No. & Treatments & $\begin{array}{l}\text { Total number of } \\
\text { leaves }\end{array}$ & $\begin{array}{l}\text { Number of infected } \\
\text { leaves }\end{array}$ \\
\hline 1 & Lawsonia inermis & $17.66 \pm 3.28 \mathrm{ab}$ & $9.03 \pm .95 \mathrm{ab}$ \\
\hline 2 & Vitex negundo & $13.33 \pm 6.17 \mathrm{~b}$ & $8.40 \pm .75 \mathrm{abc}$ \\
\hline 3 & Nicotiana tabacum & $40.33 \pm 14.26 \mathrm{ab}$ & $3.63 \pm .96 \mathrm{~d}$ \\
\hline 4 & Allium sativum & $12.33 \pm 2.60 \mathrm{~b}$ & $9.26 \pm .46 \mathrm{a}$ \\
\hline 5 & Carum roxburghianum & $11.33 \pm 3.33 \mathrm{~b}$ & $7.46 \pm .78 \mathrm{abc}$ \\
\hline 6 & Aegle marmelos & $21.33 \pm 9.20 \mathrm{ab}$ & $6.96 \pm .29 \mathrm{bc}$ \\
\hline 7 & Ficus hispida & $27.66 \pm 8.11 \mathrm{ab}$ & $6.80 \pm .34 \mathrm{c}$ \\
\hline 8 & Corchorus capsularis & $23.00 \pm 10.69 \mathrm{ab}$ & $8.56 \pm .32 \mathrm{abc}$ \\
\hline 9 & Swietenia macrophylla & $25.33 \pm 5.81 \mathrm{ab}$ & $7.90 \pm .20 \mathrm{abc}$ \\
\hline 10 & Control (tap-water) & $13.00 \pm 6.11 \mathrm{~b}$ & $8.80 \pm .50 \mathrm{abc}$ \\
\hline
\end{tabular}

Values in a column having same letter did not differ significantly $(\mathrm{P}=0.05)$ by DMRT 
Plant extract was found to have profound effect on the physiology of eggplant. In the treatment of Nicotiana tabacum, maximum plant height $(42.33 \pm 2.40 \mathrm{~cm})$ was monitored compare to control $(26.66 \pm 3.38 \mathrm{~cm})$. The second tallest eggplant $(31.00 \pm 4.04 \mathrm{~cm})$ was found in the Ficus hispida treatment (Table 3). However, extracts of seeds of Carum roxburghianum and Swietenia macrophylla showed lower plant growth, $16.33 \pm 2.18 \mathrm{~cm}$ and $15.33 \pm 2.96 \mathrm{~cm}$, respectively. Besides the Nicotiana tabacum and Ficus hispida, other extracts were found to have phyto-toxic effect to eggplant and showed negative plant growth compare to control (Table 3). Out of nine plant botanicals, the extract of Nicotiana tabacum showed five times higher production $\quad(421.28 \pm 208.05 \mathrm{~g}) \quad$ over control $(80.25 \pm 41.81 \mathrm{~g})$ in experimental eggplant field. The second highest yield $(91.87 \pm 58.30 \mathrm{~g})$ was recorded in Ficus hispida treatment. Other seven treatments showed lowest or negative level of yield compare to control (Table 3).

Table 3. Effect of plant extracts on plant height and production of eggplant

\begin{tabular}{|l|l|l|}
\hline Treatments & Plant height $(\mathrm{cm})$ & Eggplant fruit production $(\mathrm{g})$ \\
\hline Lawsonia inermis & $25.00 \pm 2.08 \mathrm{bcde}$ & $30.67 \pm 5.81 \mathrm{~b}$ \\
\hline Vitex negundo & $22.33 \pm 1.45 \mathrm{cdef}$ & $50.80 \pm 11.72 \mathrm{~b}$ \\
\hline Nicotiana tabacum & $42.33 \pm 2.40 \mathrm{a}$ & $421.28 \pm 208.05 \mathrm{a}$ \\
\hline Allium sativum & $18.66 \pm 1.33 \mathrm{def}$ & $.00 \pm .00 \mathrm{~b}$ \\
\hline Carum roxburghianum & $16.33 \pm 2.18 \mathrm{f}$ & $.00 \pm .00 \mathrm{~b}$ \\
\hline Aegle marmelos & $26.00 \pm 1.52 \mathrm{bcd}$ & $91.87 \pm 58.30 \mathrm{~b}$ \\
\hline Ficus hispida & $31.00 \pm 4.04 \mathrm{~b}$ & $68.05 \pm 41.90 \mathrm{~b}$ \\
\hline Corchorus capsularis & $17.66 \pm 1.20 \mathrm{ef}$ & $55.71 \pm 42.57 \mathrm{~b}$ \\
\hline Swietenia macrophylla & $15.33 \pm 2.96 \mathrm{f}$ & $42.52 \pm 24.57 \mathrm{~b}$ \\
\hline Control (tap-water) & $26.66 \pm 3.38 \mathrm{bc}$ & $80.25 \pm 41.81 \mathrm{~b}$ \\
\hline
\end{tabular}

Values in a column having same letter did not differ significantly $(\mathrm{P}=0.05)$ by DMRT

Leaves are important for the photo-synthetic process of plant. Plants are green as long it contains the leaves. In this experiment, leaves of some treatments were fallen first and some treatments kept the leaves for long time in eggplant (Table 4). In the treatment of Nicotiana tabacum, eggplant was found to alive with leaves for more than four months $(122.33 \pm 1.45$ days $)$ compare to control (51.00 \pm 2.08$)$. Whereas leaves in other treatments were found to fallen first due to phyto-toxic effect of some botanicals (Table 4).

Table 4. Leaves retention period in eggplant

\begin{tabular}{|l|l|}
\hline Treatments & Leaves retention period (days) \\
\hline Lawsonia inermis & $42.66 \pm 1.45 \mathrm{f}$ \\
\hline Vitex negundo & $42.33 \pm 1.45 \mathrm{f}$ \\
\hline Nicotiana tabacum & $122.33 \pm 1.45 \mathrm{a}$ \\
\hline Allium sativum & $52.33 \pm 1.45 \mathrm{e}$ \\
\hline Carum roxburghianum & $42.66 \pm 1.45 \mathrm{f}$ \\
\hline Aegle marmelos & $52.33 \pm 1.45 \mathrm{e}$ \\
\hline Ficus hispida & $60.00 \pm 2.88 \mathrm{~d}$ \\
\hline Corchorus capsularis & $87.66 \pm 1.45 \mathrm{~b}$ \\
\hline Swietenia macrophylla & $70.00 \pm 2.88 \mathrm{c}$ \\
\hline Control & $51.00 \pm 2.08 \mathrm{f}$ \\
\hline
\end{tabular}

Values in a column having same letter did not differ significantly $(\mathrm{P}=0.05)$ by DMRT

During this study, it was observed that both nymphs and adults hopper cause serious damage to the leaves of eggplant by sucking the cell sap. Eventually the entire plant turned brown and caused for the leaves drop off earlier in most of the treatments. In the treatments of Nicotiana tabacum and Corchorus capsularis were found to keep eggplant green for longer periods with sufficient number of leaves (Table 4).

The main compounds of plant extracts are different kinds of terpenoids and phenolic compounds. Botanicals contain these compounds having anti-insect activity and consider as promising alternatives to chemical insecticides. These compounds may act as effective insecticides against vegetables pests (Cork et al., 2005 ; Muyinza et al., 2010), contact insecticides (Kim et al., 2004; Tapondjou et al.,2005), repellents and anti-feedants (Park et al.,2003).

\section{Conclusions}

Out of nine botanical extracts, Nicotiana tabacum leaves extract showed excellent performance against pest attack in leaves of eggplant. Garlic bulb (Allium sativum) extract showed a very poor efficacy to protect the eggplant leaves from pest attack. Mahagoni (Swietenia macrophylla) and soj (Carum roxburghianum) seeds extracts were showed phytotoxicity and hampered the plant growth of eggplant. Tobacco (Nicotiana tabacum) enhanced the plant growth, yield and longevity of eggplant life. On the 
other hand, Allium sativum and Carum roxburghianum were caused total inhibition of eggplant fruit production. Therefore, Nicotiana tabacum was identified as a potent botanical insecticide for eggplant cultivation in Bangladesh.

\section{References}

Annonymous. 1991. Recommendations of the symposium on resources for sustainable agriculture; The use of neem and other plant materials for pest control and rural development, neem symposium. XVII Pacific Science Cngress (Honolulu; East-west center) pp. 1-11.

BARI, 1995. Annual Report 1993-94. Bangladesh Agricultural Research Institute, Joydebpur, Gazipur, Bangladesh. BBS. 2005.103p.

Berenbaum, M. R.; Niato, J. K. and Zangerl, A. R. 1991. Adaptive variation in the furanocoumarin composition of Pastinaca saliva (Apiaceae). Journal Chemical Ecology, 17: 207-215.

Chen, W.; Isman, M. B. and Chiu, S. F. 1995. Antifeedant and growth inhibitory effects of the limonoid toosendanin and Mclia loosendan extracts on the variegated cutworm, Peridroma saucia. Journal Applied Entomology, 119: 367370.

Cork, A.; Alam, S. N.; Talekar, N. S. and Jhala, R. C. $2005^{\mathrm{a}}$. Development and commercialization of mass trapping for control of eggplant borer in South Asia. Proceeding of 4th International Conference on Biopesticides: Phytochemicals and natural products for the progress of mankind'. 1318 February 2005, Chiang Mai, Thailand.

Cork, A.; M. J.; Kamal, N. Q.; Choudhury, J. C. S.; Rahman, M. M. and Islam, M. 2005 ${ }^{\mathrm{b}}$. An old pest, a new solution - Commercializing rice stem-borer pheromones in Bangladesh. Outlook on Agriculture, 34(3): 181-187.

Halliday, W. R.; Arthur, F. H. and Zettler, F. H. 1988. Resistance status of red flour beetle (Coleoptera: Tenebrionidae) Infesting stored peanuts in south eastern United States. Journal of Economic Entomology 81: 74-77.

Hiremath, I. G.; Young Joon, A.; Kim-Soon. I. and Kim S. 1.1997. Insecticidal activity of Indian plant extracts against Nilaparvata lugens (I lomoptcra: Delphacidae). Applied Entomology and Zoology, 32: 159-166.

Huang, H. S.; Hu, N. T.; Yao, Y. E.; Wu, C. Y.; Chiang, S. W. and Sun, C. N. 1998. Molecular cloning and heterologous expression of a glutathione S- translcrasc involved in insecticide resistance from the diamond back moth, Plutella xylostella. Insect Biochemistry and Molecular Biology, 28: 65 1-658.

Isman, M. B. 1995. Leads and prospects for the development of new botanical insecticides. In: Reviews in Pesticide Toxicology (Roe, R. M. and Kuhr, R. J. eds.), Toxicology Communications Inc., Raleigh, NC, 3: 1-20

Jacobson, M. 1989. Botanical insecticides. Past, present and future. In: Insecticides of Plant Origin. American Chemical Society (Amazon, J. T.,
Philogene, B. 1. R.and Morand, P. eds.), Symposium Series No. 387, Washington, D. C., pp. 1-10.

Kim, H. K.; Kim, J. R. and Aim, Y. J. 2004. Acaricidal activity of cinnamaldehyde and its congeners against Tyrophagus putrescentiae (Acari: Acaridae). Journal of Stored Product Research, 40: 55-63.

Klepzig, K. D. and Schlyter, F. 1999. "Laboratory evaluation of plant derived antifeedants against European pine weevil, Hylobius abietis" Journal of Economic Entomology, 92: 644-650.

Muyinza, H.; Stevenson, P. C.; Talwana H.; Hall, D. R.; Farman, D. I. and Mwanga, R. O. M.. 2010. Root Chemicals could offer opportunities for breeding for Sweet Potato Resistance to the Weevil Cylas puncticollis Boheman (Coleoptcra: Apionidac). Aspects Of African Biodiversity: Royal Society Of Chemistry Special Publication, 321: 49-57.

Park. J. D.; Ann, Y-J.; Park, I-K; Lcc, S-G. and Choi, D-H. 2003. Insccticidal activities of constituents identified in the essential oil from leaves of Chamaecyparis obtusa against Callosobruchus chinensis (L.) and Sitophilus oryzae (L.). Journal of Stored Product Research. 39: 375-384.

Sadek, M. M. 2003. Antifeedant and toxic activity ofAdhaloda vasicq leaf extract against Spodopleru littoralis (Lepidoptera: Noctuidae). Journal Applied Entomology, 27: 396-404.

Saxena, R. C.; Liqudo, N. J. and Justo, H. B. 1980. Neem seed oil an antifecdanl for brown plant hopper. Proc. $1^{\text {st }}$. Int. Neem Conf. Rottach, Egern, W. Germany, June, 1980, pp. 171-188.

Schmutterer, 1990. Properties and potential of natural pesticides from the neem tree. Annual Review of Entomology, 30: 698-700.

Talukder,F. A. and Howse, O.E. 1993. Deterrent and insecticidal effects of extract of pithraj, Aphanamixis polistachya against Tribilium castanium in Storage. Journal of Economic Entomology Journal of Chemical Ecology. 19 (11): 2463-2471.

Tapondjou, A. L.; Adler, C.; Fontem, D, A.; Bouda, H. and Rcichmuth, C. 2005. Bioactivitics of cymol and essential oils of Cupressus sempervircns and Eucalyptus saligna against Sitophilus zeamais Motschulsky and Tribolium confusum du Vai. Journal of Stored Product Research, 41(1): 91102.

Wheeler, D. A. and Isman, M. B. 2001. Antifeedant and toxic activity of Trichilia Americana extract the larvae of Spodoptera litura. Entomologia Experimentalis et Applicata, 98: 9-16. 